\title{
Discourse, Power and Truth: Foucauldian Perspective
}

\section{Prakash Bhattarai}

Kirtipur Secondary School, Kirtipur Kathmandu, Nepal

\begin{abstract}
Discourse is the stretches of language which is socially used to convey broad conventional meaning. This theoretical study 'Discourse, Power and Truth: Foucauldian Perspective' reveals the social and educational perspectives of discourse, power and truth along with their basic concept. Being based on different literatures reviews and the concepts the author got in philosophy class at Tribhuvan University, this study aims to provide insights to those who want to get basic concept on Foucauldian perspective on discourse, power and truth. From the study, it was found that discourse is not only a linguistic phenomenon rather it is social too. It is identified by the social conditions of its use, by who is using in what contexts. Discourse is both means and effect of power.
\end{abstract}

Keywords-Discourse, power, truth/knowledge, Foucault.

\section{INTRODUCTION}

Foucault, originally named Paul-Michel Foucault, was born on October 15, 1926, in Poitiers whereas he died of an AIDS related illness in 1984 (Olsson, 2010). He generated and introduced a number of theories throughout his life. His theories chiefly address the relationship between power and knowledge and how they are used as a form of social control through societal institutions. His thoughts on discourse, power and knowledge/truth are very much popular among the academicians. Here, the basic concepts of these terms along with their relationship is discussed in the subsequent paragraphs.

The concept "discourse" has a number of definitions and interpretations on the basis of context. Discourse can be simply defined as a discussion on any subject matter either in speech or writing. A plethora of literature notes that in the study of language, discourse often refers to the speech patterns and usage of language, dialects, and acceptable statements within a community ( Pitsoe \& Letseka, 2013, p. 24). For Foucault (1972), discourses are about what can be said and thought, but also about who can speak, when, and with what authority. In other words, discourse is controlled in terms of objects (what can be spoken of), ritual (where and how one may speak) and privileged or exclusive right to speak of certain subjects (who may speak) ( Pitsoe \&
Letseka, 2013). To summarize in one sentence, all utterances/ texts which have meanings and have some effects in the real world, count as discourse. From these views, it is clear that discourse is not only structural/ linguistic phenomenon rather social too.

Power, to take it simply, is preventing someone from carrying out wishes and limiting someone's freedom. To put it in other way, it is the ability and/or authority to control people or things. Power tends to be associated with competition at best, coercion or domination at worst ( Karlberg, 2005). Foucault (1972, p. 94) defines power as not something that is acquired, seized or shared, something one holds onto or allows to slip away. Similarly, Foucault (1979 in Olsson, 2010) states, "Power is everywhere; not because it embraces everything but because it comes from everywhere. ... Power comes from below; that is there is no binary and all-encompassing opposition between rulers and ruled at the root of power relations ... no such duality extending from the top down." From this view what we can say is power is not exercised by a few individuals over the many, but something to which everyone is subjected.

Knowledge, to define it simply, is the understanding, skills that we get through education and experience. For Foucault, knowledge /truth is neither based on a perceived correspondence with an objective reality... 
nor is it wholly subjective... rather it is inter subjective--a product of the shared meanings, conventions, and social practices operating within and between discourses, and to which an individual's sense-making processes are inextricably linked (Olsson, 2010, p. 66).To put it in other way, it is something which societies have to work to produce rather than something which appears in a transcendental ways.

\subsection{Research Questions}

This article tries its utmost to discover the answers of the following research questions. In other words, this article is guided by these research questions.

a) How are discourse, power and knowledge/ truth interrelated?

b) What are the social impacts and educational implications of Faucauldian's view on discourse, power and knowledge/ truth?

\subsection{Rationale of the Study}

Normally, people view discourse from structural point of view though it is a social phenomenon. Discourse is a stretch of language either in written or in spoken form. Such stretches are always used in our societies. It means to say that language is not used in vacuum. Foucault's view on discourse reveals the relationship between language (discourse) and society on one hand and the relationship between discourse and power on the other. In other words power is linked to the formation of discourse. The social world, expressed through language, is affected by various sources of power. From this discussion it is clear that discourse and power are interrelated both being part of society. Yet, how they are connected and to what extend is the matter of study, so this present study is done.

\section{METHODOLOGY}

This study is the product of the thematic document analysis related to discourse, power and truth/knowledge after PaulMichel Foucault (1926- 1984). Being a qualitative study, based on interpretivism research paradigm, this study reveals the fact that discourse, power and truth/knowledge has multiple interpretations. These interpretations are based on the contexts where they are used and such interpretations differ from context to context. To bring this theoretical article in this form, different literatures related to discourse, power and knowledge were reviewed to get insights on these concepts in general and Foucauldian view in particular. The main theoretical base for this article is Foucault's 'The ISSN: 2456-7620 archaeology of knowledge and discourse' published in 1972. In the similar vein, the works such as Karlberg (2005), Pitsoe and Letseka ( 2013), I (2008) and so on are some empirical research from where the ideas were generated. Secondly, I incorporated the ideas and feedback from my colleagues and professor I had got after presenting a group presentation on the very topic at my M.Phil. Finally, I compiled all the ideas from different sources and explained relating them in our own social and educational context using thematic analysis technique.

\section{RESULT AND DISCUSSION}

This section mainly deals with the relationship between discourse, power and truth and how they are connected with society. Moreover, it suggests some educational implications of Foucauldian view on discourse, power and truth.

\subsection{Discourse, Power and Truth: Their Relationship}

Discourse is interwoven with power and knowledge to constitute the oppression of those "others" in our society, serving to marginalize, silence and oppress them ( Pitsoe \& Letseka, 2013, p. 24). It means to say that discourse is interconnected with both power and knowledge to constitute the oppression of different marginalized groups. Discourse can be both means and effect of power. It is discourse that helps us to be in power at the same time our discourses are affected and guided by the power we possess. Let's take feminism as a discourse. Women can be empowered with the help of this discourse on one hand and they can be steered with this this discourse on the other. So we can say, power and knowledge are two sides of a single process.

Discourse is not merely a tool of domination rather it is an instrument of power. In other words, discourse not only dominate those who do not have power rather it gives them the strength to seize power. For Foucault (1977 as cited in Pitsoe \& Letseka, 2013 p. 24), "It is through discourse (through knowledge) that we are created; and that discourse joins power and knowledge, and its power follows from our casual acceptance of the "reality with which we are presented." In Foucault's view, discourses are never static. Rather, the ongoing relations between people, institutions and texts generate regimes of both meaning and authority (power/knowledge) simultaneously (Olsson, 2010). 


\subsection{Discourse, Power and Truth as Socially Constructed Phenomena}

Foucault (1980 in Karlberg, 2005) understands power as a relational force that permeates the entire social body, connecting all social groups in a web of mutual influence. As a relational force, power constructs social organization and hierarchy by producing discourses and truths, by imposing discipline and order, and by shaping human desires and subjectivities. Similarly, Pitsoe and Letseka (2013 p. 25) states, "Power is both a social and multi-layer construct...it is a product of social relations and is culturally, socially and symbolically created." From the ideas presented here, it is clear that power is a social phenomenon which is created socially.

Truth, on the other hand, is also something which societies have to work produce rather than something which appear in a transcendental way. Truth/knowledge is as power is socially and culturally created. In this regard Pitsoe and Letseka (2013, p. 24) states, "Foucault suggests that each society has its regime of truth, its "general politics" of truth: that is, the types of discourse it accepts and makes function as true; the mechanisms and instances which enable one to distinguish between true and false statements." What society accepts as truth/knowledge is knowledge in its true sense. In other words, the discourse which is accepted by our society is truth/ knowledge.

Foucault views discourse from social perspective rather than structural point of view. Discourse, as a social construct, is created and perpetuated by those who have the power and means of communication ( Pitsoe \& Letseka, 2013). In every society the production of discourse is at once controlled, selected, organized and redistributed according to a certain number of procedures, whose role is "to avert its powers and its dangers, to cope with chance events, to evade its ponderous, awesome materiality" ( Pitsoe \& Letseka, 2013). Discourse is not used in vacuum. It means to say that it is society where discourse is used. It is guided by social norms, values and power.

Discourse is action guidance for social movements. It is a means of social change and reform. If we have a quick look to our history of our social change and reformation, we can easily find the role of discourse for such changes and reformations. In other words, it is discourse that makes all type of changes and reformations possible. Moreover, it plays a vital role for conflict management and culture preservation and transmission.

\subsection{Schools as Institutions for Social Reproduction}

As Foucault (1972) states, "Every educational system is a means of maintaining or modifying the appropriateness of discourses with the knowledge and power they bring with them." Education may well be, as of right, the instrument whereby every individual, in a society like our own, can gain access to any kind of discourse. However, we well know that in its distribution, in what it permits and in what it prevents, it follows the well-trodden battle lines of social conflict. Every education system is a political means of maintaining or of modifying the appropriation of discourse, with the knowledge and the powers it carries with it (Foucault, 1972). In the similar vein, Pitsoe and Letseka (2013) state, "Schools are institutions for social reproduction and the classrooms are key sites for the reproduction of social identities and unequal relations of power."

Foucault's view on discourse, power and knowledge has a number of educational implications. Such implications can be seen both in curriculum and pedagogy. Going through the present curriculums of different levels what can be seen is the curriculums focus on discourse and interaction. Such curriculums highlight on contents which focuses on social class and power relations. Pedagogy that focuses on active learning/participatory process which demands interaction, discussion and critical thinking on the part of students is one of the most influencing educational implications of Foucauldian view.

\section{REFLECTION}

The way we talk and think about a subject display the ways we act in relation to that subject. It means to say that our actions are always guided by our thoughts. And our thoughts, on the other hand, are guided by our social values and norms and our power relations. These ideas give the concept that our discourse is guided by social perspective on one hand and the power that we possess. Foucault views discourse and power from social perspective rather than structural one, and I stand along with Foucault's view since these two terms discourse and power are parts of our society. They cannot be made separate from our society. Discourse is a means and effect of power as Foucault opines. If we closely observe our society, we find this statement as a true one. From my perspective too, it is discourse that enables any member of society to achieve power. A person becomes powerful due to a long discursive practice. Similarly, the one who is in power or possesses power has different discursive practice. The 
discourse made by such person has high value in the society. Such discourse is accepted by the society which later on becomes knowledge/truth to every member of the society. The reasons presented here made me stand with Foucauldian perspective on discourse, power and truth.

\section{CONCLUSION}

Structurally, discourse can be defined as linguistic utterance which can be in written or spoken form. But discourse is not only linguistic and structural phenomenon but social and cultural practice of language that can influence and shape the world issues, and this is shaped by social perspective. It is not stable rather it is changeable which is always steered by progresses and ideologies of society. Discourse is both means and effect of power. The power of the world lies on discourse and our discourse is always guided by the power that we possess. Similarly, people's understandings of the world are shaped and expressed by discourse. The discourse becomes knowledge/ truth only when it is verified by our society. In other words, any discourse can be knowledge/truth after the society accepts it. Foucault focuses mainly on the social perspective of discourse rather than structural one due to which discourse cannot be separated from society. Discourse, power and knowledge have not only social impacts but also a number of educational implications.

\section{REFERENCES}

[1] Baumgarten, B., \& Ullrich , P. (2012). Discourse, power and governmentality: Social movement research with and beyond Foucault. Wissenschaftszentrum Berlin für Sozialforschung (WZB). Retrieved from hdl.handle.net/10419/71402

[2] Foucault, M. (1972). The archaeology of knowledge and the discourse. New York: Pantheon.

[3] I, J. (2008). Discourse analysis and Foucault's " Archaeology of knowledge". International Journal of Caring Sciences, 1(3), 107-111.

[4] Karlberg, M. (2005). The power of discourse and the discourse of power: Pursuing peace through discourse intervention. International Journal of Peace Studies, 10(1 Spring/Summer), 1-23.

[5] Olsson, M. R. (2010). Michel Foucault: Discourse, power/ knowledge, and the battle for truth. In G. J. Leckie, L. M. Given, \& J. E. Buschman, Critical theory for library and information science (pp. 63-74). Santa Barbara, California: Libraries Unlimited.

[6] Pitsoe, V., \& Letseka, M. (2013). Foucault's discourse and power: Implications for instructionist classroom management. Open Journal of Philosophy, 3(1), 23-28.
[7] Sharma, B. (2011). Readings in pragmatics and discourse analysis. (C. Mishra , Ed.) Kathmandu: Sunlight Publication. 